\title{
Evaluation of the
}

\section{Dormitories in the Physical} and Psychological Requirements: The Case of Karabük Province

\section{S. Merve Öztürk* Ahmet E. Dinçer ${ }^{* \star}$}

\section{Abstract \\ Purpose}

The aim of this paper is to investigate the problems of meeting students' housing needs in many cities that could not adapt to this change with its infrastructure against the rapid increase in the number of Turkish universities and students, who are educated in these institutions, in recent years. In addition, it is to develop alternative suggestions concerned with design criteria for increasing qualifications of the dormitories as one of the primary housing alternatives for students.

\section{Design/Methodology/Approach}

Users' preferences and their management are very important for especially multi-user design processes. Hence, through a survey, it was planned to determine the physical conditions and the spatial characteristics of the existing dormitories beside their conformities in terms of the users' satisfaction. At the end of the extensive literature research, the evaluation criteria which included basic psychological
Keywords: Dormitory, housing, physical and psychological requirements, Planning principles.

*Res. Asst. Faculty of Architecture, Karabük University, Turkey.

Email: smozturk@karabuk.edu.tr ORCID No: https://orcid.org/0000-00022790-067X

**Asst. Prof. Dr. Faculty of Architecture. Karabük University, Turkey. Email: aedincer@karabuk.edu.tr ORCID No: https://orcid.org/0000-00023439-3637 
(privacy, sense of crowded, belonging and socializing, etc.) and physical (dorm rooms, social and service areas in the dorms and the dorms' environment, etc.) factors were prepared for the survey. Then their validity was tested via the survey questions and the SPSS software. The obtained findings in the study were discussed in the frame of previous literature researches and their results. Evaluations were made in terms of the development of architectural planning principles of dormitory buildings.

\section{Findings}

Some outstanding findings and evaluations were listed as increasing the more customized using areas in the rooms, rehabilitation of study areas, multiplying variations of study and socializing areas, organizing social areas as partial units instead of the only central space for different functions, avoiding large-scale dormitories for decreasing the perception of crowded sense, creating flexible environments according to the conditions, etc. Besides, although the spatial planning of the dormitories was commonly compatible with the standards, the organization disorders like overcapacity and change of functions have been found to cause dissatisfaction. Many of these are thought to be innovative inputs for the design stages of dormitory buildings even if design contexts are different.

\section{Research Limitations/Implications}

The survey is conducted in Karabük with 250 students from different faculties in Karabük University whose development process has significantly affected the city and the city life in the last decade. So, the conditions of dormitories in Karabuk are examined.

\section{Practical Implications}

it is necessary to consider the users' opinions and expectations about these buildings in the frame of their changing lifestyles and thus to review the criteria and approaches in designs of such buildings.

\section{Social Implications}

The fast and immediate solutions which have been done without considering in detail are often not useful. So, on behalf of solving this rapidly growing problem which has encountered in many cities in similar ways, improving them in line with the current user needs and thus increasing qualities in the students' education and life standards, it is important to examine the conditions of the dormitory buildings which have been constructed or will be constructed.

\section{Originality/Value}

In this study, unlike the other dormitory studies, the design problems and user interactions have been evaluated with a more holistic approach from interior organization to the decisions on an urban scale.

\section{INTRODUCTION}

Besides producing scientific, cultural and artistic studies by providing academic education to young people in terms of their basic aims, universities contribute to the knowledge level of the society in different fields by supporting the cities, in which they are, economically. However, the rapid growth of the cities, in which the newly established universities are in recent years, is remarkable. With this growth, as the increase in the numbers of 
students and instructors has effects on the construction facilities, it leads to significant changes in city planning. Karabük province, which is chosen as a research area, shares a similar process with the sample cities which have newly established universities, in Turkey. Since the establishment of Karabük University in 2007, the city has shown rapid development and a change in a short time. As a result of its positive relationships with the city, the university has made a lot of contributions from social, cultural and economic aspects. Nevertheless, because the city is not ready for this rapid development, various problems have emerged. The most important one is the housing problems for the students who have to get an education away from their families. In parallel to the number of students, the intense increase in the demand for housing and dormitory is the main factor in the transformation of housing to this problem. Especially, the rapid development, which doesn't take care of environmentalist data and has proceeded in an uncontrolled manner due to the need, caused to loss of the qualification in the dormitory buildings where the students spend most of their time out of the school. However, in the design of the dormitories, the ignorance of factors that support students in many ways socially or culturally and should be considered with all aspects has given rise to negative effects on the students' academic success. All these reasons demonstrate that the research area is a region worth examining. In this study, the survey has been made on users of these buildings with data which was obtained in the result of examining architectural projects of the dormitories in Karabük and reviewing the literature, and its results have been evaluated and discussed.

\section{LITERATURE REVIEW}

In literature, there are many studies made with different perspectives concerning this subject. Some of the prominent criteria which were obtained from these studies have been used in the evaluation and interpretation of the physical conditions and physiologic effects of the dormitories in Karabük. Dormitories are the spaces where the students from different cultures and with their different characters come together. Therefore, the design process of these buildings should be evaluated both in detail and in a holistic view. It is possible to see reflections and the requirements of this approach in the chosen samples.

The physical environment where students live has different effects on their cognitions. In dormitories which are temporary accommodations, it is expected to make solutions that will increase students' sense of belonging. The extreme formalism is one of the most important obstacles to the sense of belonging. 
İnceoğlu (1995) criticized that a large part of the dormitories was in the form of having a linear corridor and a series of rooms that aligned at both two sides of this corridor. He suggested that the arrangements of the rooms around the halls instead of the corridors with small units could reduce the formal effects (İnceoğlu, 1995). On the other hand, Rodger and Johnson (2005) found that the sense of belonging among students living in suitestyle dormitories whose rooms include sleeping, socializing, cleaning, eating-drinking areas together was more than among the students living in the traditional dormitories with the corridor. Similarly, Khozaei et al. (2014) emphasized that suitestyle rooms were commonly preferred and the presence of living/using areas that were determined clearly in the spaces was in demand.

Kaya and Erkip (2001) concluded that the students felt that the room sizes were larger and less crowded on the upper floors compared to the lower floors. Middle flats are the most preferred for use due to ease of accessibility and fewer noise problems (Khajehzadeh \& Vale, 2014). In addition to building floor organizations, interior designs and density of the used furniture elements in the room's effect on students' satisfaction (Yildirim \& Uzun, 2010). In dormitory room organizations, ergonomics and material preferences play an important role in students' perceptions (Çağatay et al., 2014)

In their studies which examined intercultural privacy criteria in the context of Turkey and America, Kaya and Weber (2003) found that American students needed more privacy than Turkish students. They correlated this result with the fact that Turkish people can adapt to the socially intensive environment due to the strong intrafamilial ties and friendships of Turkish society which differentiated from Western society with its culture. Devlin et al. (2008) gave some pieces of advice on the development of social sense by the means of design. In the study, they stated that the organizations where the rooms were located around a center were more successful in the development of socialization, but large-scale dormitories left behind in this subject with the effects of noise and sharing spaces. Similarly, Demirbilek (2012) pointed out that friendship relations in the dormitories were affected by social grouping and the physical conditions like noise and loss of privacy areas due to increasing numbers of the person in the rooms.

In the examined studies, it is observed that the focus is usually on the problems of general floor plan organizations, however, the review of the design of sub-spaces and space in floor plan and room design has not been handled adequately. 


\section{METHOD}

In literature, when the studies related to dormitories are observed, it seems that the effects of space have been researched on subjects like senses of belonging, privacy, and crowd which are based on psychology. In the other studies which examined the physical qualities of dormitory buildings, the subjects such as the area-volume needs of spaces, space organizations and the adequacy of the units in these organizations according to their service have been the titles of the research. By the aim of evaluating the architectural qualities of the dormitories in Karabük, in a holistic approach, this research is based on the expectations and satisfaction of the students educated in Karabük University in the 2017-18 academic year about the dorms they stayed. In this study in parallel with the researches on the subject, the problems of the dormitories in Karabük, whose design planning principles have been previously examined in detail, were determined (Öztürk, 2017). In the research, in the frame of the previous researches in the field, the assessment criteria on the designs of the dormitories in Karabük were determined to measure the effects of the psychological and physical qualities of the spaces on the students. The following criteria were tested:

- $\mathrm{C}_{1}$ : The existence of the specialized sub-spaces which are successful in meeting the sense of belonging and privacy is a reason for the students' preference.

- $\mathrm{C}_{2}$ : The increase in numbers of users in rooms and dormitory buildings affects negatively students' preferences.

- $C_{3}$ : Besides the numbers of furniture/equipment in the rooms, their organization is also effective on satisfaction.

- $\mathrm{C}_{4}$ : Designs of common/service spaces (cleaning area, laundry, etc.) in dormitories have an important effect on students' satisfaction.

- $\mathrm{C}_{5}$ : Designs of social spaces (restroom, study hall, TV room, garden, etc.) in dormitories have an important effect on students' satisfaction.

- $\mathrm{C}_{6}$ : Besides interior space organizations building façade designs also affects students' preferences.

Frequency analysis was used to test the criteria. When starting the survey study, the information about numbers and capacities of the dormitories in Karabük was obtained from Higher Education Credit and Hostels Institution (YURTKUR) and Ministry of National Education (MEB) which are the supervisor of these institutions. According to the obtained data in 2017, while there were seven public dormitories in the control of YURTKUR, the numbers of private dormitories supervised by 
MEB were 19. Karabük city and Safranbolu town were chosen as study areas, while 6741 students benefited from accommodation services in the private dormitories in the control of MEB, 9128 students stayed in the public dormitories, which belong to YURTKUR. The survey sampling consisted of 250 participants who were selected randomly among the students who were educated at Karabük University and stayed in the dormitories. The participants were predominantly the students in faculties of Architecture, Safranbolu Fine Arts and Design and Engineering (Department of Civil Engineering); and Safranbolu Vocational School (Department of Restoration).

The survey included the questions which were prepared to determine the students' expectations from a dormitory building and to evaluate their reviews of the dormitories, in which they stay, for use in the design of a dormitory in the future. There are three sections in the survey. In the first section, there were multiple-choice questions aimed at obtaining students' sociodemographic characteristics and the basic information about the dormitories, in which they stayed. The content of the second section is concerned with the determination of students' expectations and reviews about the spaces which should be in a dormitory. The third section contains students' evaluations of the organizations of existing and active dormitories. In the second and third sections, a five-point Likert scale was used in the evaluations of students' expectations and existing conditions of the dormitories except for the questions about dormitory building and numbers of people in a room.

In the result of the survey, the obtained data were evaluated by SPSS software (statistical package for social sciences). In the analysis, the questions were discussed respectively, and the frequency, percentage and standard deviations were calculated for students' participation level in the questions. The data was presented in the tables.

\section{FINDINGS}

The statistical analysis method was applied to the survey which was conducted on the students at Karabük University and the results were discussed. As stated before, in the first section demographic information about students is given. While table 1 is viewed, the results are as follow: 
Evaluation of the Dormitories in Terms of the Physical and Psychological Requirements: The Case of Karabük Province

Table 1. Demographic information about the students participating in the study

\section{Section I: Personal Information}

\begin{tabular}{|c|c|c|c|}
\hline & & $\mathbf{F}$ & $\%$ \\
\hline \multirow[t]{2}{*}{ 1. What is your gender? } & Female & 110 & $\overline{44}$ \\
\hline & Male & 140 & 56 \\
\hline \multirow{4}{*}{$\begin{array}{l}\text { 2. What is your cumulative } \\
\text { grade point average? }\end{array}$} & Under 2.00 & 56 & 22,4 \\
\hline & Between 2.00-2.50 & 92 & 36,8 \\
\hline & Between 2.50-3.50 & 102 & 40,8 \\
\hline & Between 3.50-4.00 & 0 & 0 \\
\hline \multirow{4}{*}{$\begin{array}{l}\text { 3. How many years have } \\
\text { you been living in the } \\
\text { dormitory? }\end{array}$} & Less than one year & 142 & $\overline{56,8}$ \\
\hline & Between 1-2 years & 62 & 24,4 \\
\hline & Between 3-4 years & 29 & 11,6 \\
\hline & More than four years & 18 & 7,2 \\
\hline \multirow{2}{*}{$\begin{array}{l}\text { 4. What is the type of dorm } \\
\text { you stay in terms of } \\
\text { administration? }\end{array}$} & Public Dormitory & 115 & 46 \\
\hline & Private Dormitory & 135 & 54 \\
\hline \multirow{4}{*}{$\begin{array}{l}\text { 5. How many people do you } \\
\text { stay in the room? }\end{array}$} & One person & 18 & 7,2 \\
\hline & Two people & 78 & 31,2 \\
\hline & Three people & 59 & 23,6 \\
\hline & $\begin{array}{l}\text { More than four } \\
\text { people }\end{array}$ & 95 & 38 \\
\hline \multirow{4}{*}{$\begin{array}{l}\text { 6. Where would you prefer } \\
\text { to stay if you had a chance } \\
\text { to choose or your budget } \\
\text { was available? }\end{array}$} & With my family & 97 & 38,8 \\
\hline & Private Dormitory & 24 & 9,6 \\
\hline & Public Dormitory & 15 & 6 \\
\hline & Student Home & 114 & 45,6 \\
\hline \multirow{5}{*}{$\begin{array}{l}\text { 7. What is your reason for } \\
\text { staying in a dorm? }\end{array}$} & Being economic & 108 & 43,2 \\
\hline & Being Close to school & 67 & 26,8 \\
\hline & Being comfortable & 27 & 10,8 \\
\hline & Being secure & 36 & 14,4 \\
\hline & My friends stay & 12 & 4,8 \\
\hline
\end{tabular}


- In the evaluation, the answers of 250 students (110 male and 140 female) were examined. According to this, $44 \%$ of the participants are male and $56 \%$ of those are female students.

- $46 \%$ of the participants stayed in the public dormitories and $54 \%$ of them lived in the private dormitories.

- Considering the duration of life in dormitories it seemed that many of the students stayed in these buildings for less than one year $(56,8 \%)$.

- When the numbers of people in the rooms are examined, it is observed that the participants commonly lived in the rooms with two people $(31,2 \%)$ and the rooms with four and more people (38\%).

- In terms of the types of accommodation buildings which participants can choose to stay if they have a choice, it was observed that the most preferred options were that of "student house" (45\%) and that of "their family houses" $(38,8 \%)$, but the options of "public dormitories" (6\%) were the least preferred.

- While asking reasons for staying in a dormitory to participants, it is noteworthy that most of them chose to stay in these buildings because of economic conditions $(43,2 \%)$.

In the second section, the questions about students' expectations about dormitory buildings were asked. While Table 2 is examined, the obtained results can be explained as follow:

- In response to the question "how many people does the crowd sense starts to be felt with in a dormitory" when $40,8 \%$ of participants pointed out "More than 100 people", $40 \%$ of that signed "more than 500 people" in the survey. Considering the conditions of public dormitories whose capacities have changed between 750 and 3000 people, this result is important and supports $\mathrm{C}_{2}$ criteria.

- It is noteworthy that $50.4 \%$ of the students stated that they should have double-dorm rooms. This result is concerned with the criteria in $\mathrm{C}_{2}$.

- In this section, the questions prepared on the 5-point Likert scale are related to the separation of rooms and flats into the spaces, which have sub-functions, by aiming at determining students' needs of privacy. Regarding spaces that are expected to be in the room and are necessary for students, the rates of participants' answers of "I agree completely" were listed as $79.2 \%$ about the private bathroom, $50.8 \%$ about the resting-living area, $72.4 \%$ about the work area. Furthermore, in terms of the spaces which are expected to be in common use and are necessary for students in a flat, the rates of participants' answers of "I agree completely" 
Evaluation of the Dormitories in Terms of the Physical and Psychological Requirements: The Case of Karabük Province

resulted as $42,8 \%$ about the kitchen, $45,2 \%$ about studying areas, 37\% about resting area. These results support the criteria proposed in $\mathrm{C}_{1}$.

Table 2. Information on participants' expectations from a dormitory building. Section II: Expectations From A Dormitory Building

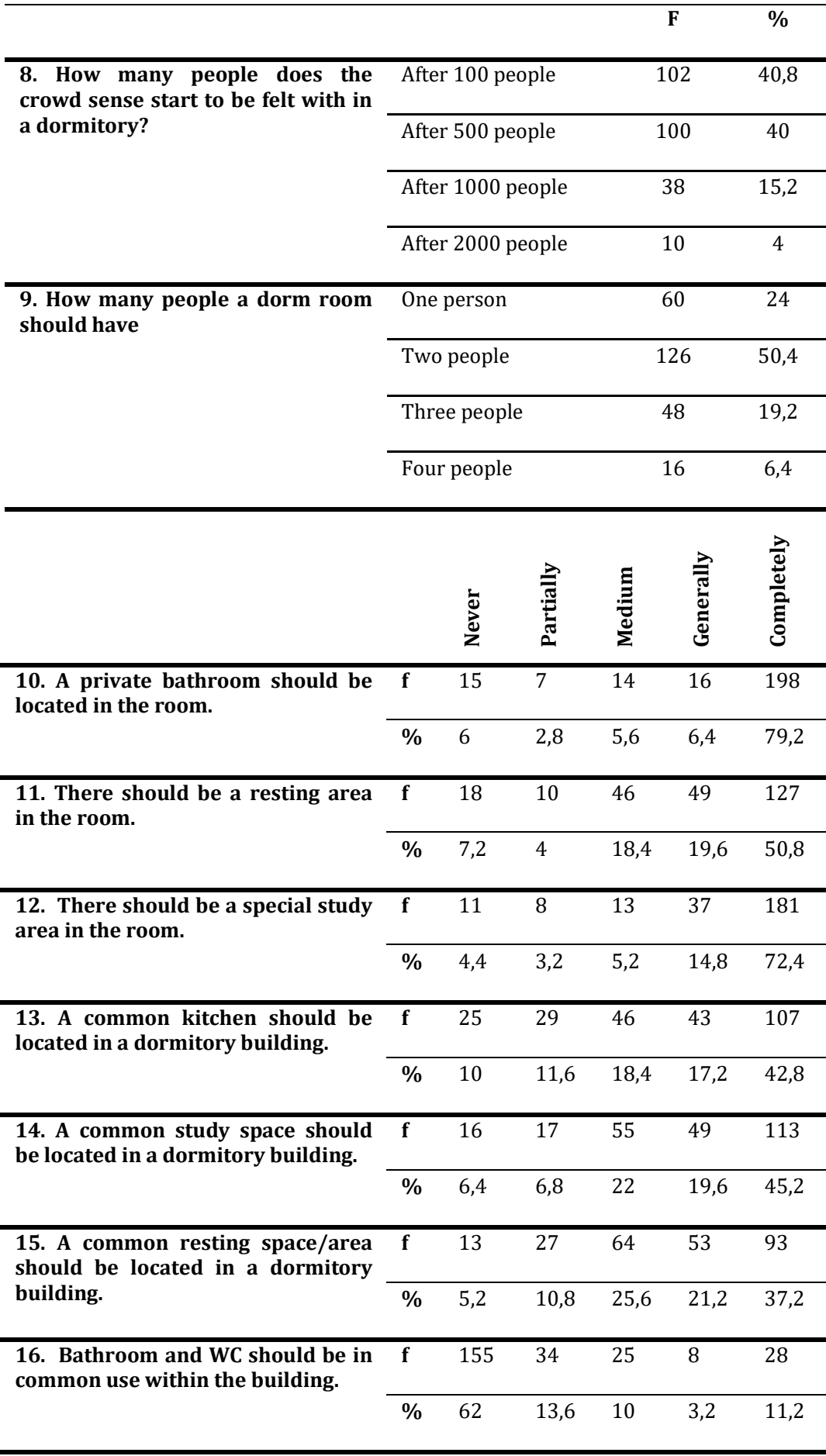

In the third section, students were expected to evaluate the dormitories where they resided. When table 3 is examined; 
Table 3. The information about students' opinions concerned with the dormitories where they live.

\section{Section III: Opinions About The Dormitory}

\begin{tabular}{|c|c|c|c|c|c|c|}
\hline & & $\begin{array}{l}\bar{d} \\
\dot{d} \\
z\end{array}$ & 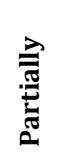 & 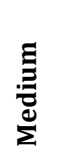 & 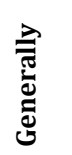 & $\frac{\frac{\lambda}{d}}{\frac{d}{a}}$ \\
\hline \multirow{2}{*}{$\begin{array}{l}\text { 17. I'm pleased with the } \\
\text { number of people in the room. }\end{array}$} & f & 42 & 24 & 78 & 34 & 72 \\
\hline & $\%$ & 16,8 & 9,6 & 31,2 & 13,6 & 28,8 \\
\hline \multirow{2}{*}{$\begin{array}{l}\text { 18. I think that the study area } \\
\text { is adequate in the room. }\end{array}$} & f & 72 & 72 & 49 & 21 & 37 \\
\hline & $\%$ & 28,8 & 28,4 & 19,6 & 8,4 & 14,8 \\
\hline \multirow{2}{*}{$\begin{array}{l}\text { 19. I'm pleased with the } \\
\text { location of the study area in } \\
\text { the room. }\end{array}$} & $\bar{f}$ & 71 & 54 & 67 & 24 & 34 \\
\hline & $\%$ & 28,4 & 21,6 & 26,8 & 9,6 & 13,6 \\
\hline \multirow{2}{*}{$\begin{array}{l}\text { 20. The numbers of furniture } \\
\text { (table, cupboards, etc.) are } \\
\text { consistent with the numbers of } \\
\text { users. }\end{array}$} & f & 42 & 31 & 58 & 41 & 78 \\
\hline & $\%$ & 16,8 & 12,4 & 23,2 & 16,4 & 31,2 \\
\hline \multirow{2}{*}{$\begin{array}{l}\text { 21. I think that the size of the } \\
\text { room is sufficient in terms of } \\
\text { numbers of people. }\end{array}$} & f & 66 & 50 & 59 & 37 & 38 \\
\hline & $\%$ & 26,4 & 20 & 23,6 & 14,8 & 15,2 \\
\hline \multirow{2}{*}{$\begin{array}{l}\text { 22. I think that the social areas } \\
\text { where I can spend my free } \\
\text { time in the dormitory are } \\
\text { enough. }\end{array}$} & $\bar{f}$ & 93 & 67 & 44 & 24 & 22 \\
\hline & $\%$ & 37,2 & 26,8 & 17,6 & 9,6 & 8,8 \\
\hline \multirow{2}{*}{$\begin{array}{l}\text { 23. The study area is not } \\
\text { enough in the room }\end{array}$} & f & 46 & 43 & 53 & 40 & 68 \\
\hline & $\%$ & 18,4 & 17,2 & 21,2 & 16 & 27,2 \\
\hline \multirow{2}{*}{$\begin{array}{l}\text { 24. I'm pleased with the } \\
\text { organization of furniture in } \\
\text { the room. }\end{array}$} & $\bar{f}$ & 50 & 39 & 93 & 45 & 23 \\
\hline & $\%$ & 20 & 15,6 & 37,2 & 18 & 9,2 \\
\hline \multirow{2}{*}{$\begin{array}{l}\text { 25. Service units (laundry, } \\
\text { shared bathrooms, etc.) in the } \\
\text { dormitory are sufficient. }\end{array}$} & $\bar{f}$ & 53 & 54 & 74 & 41 & 28 \\
\hline & $\%$ & 21,2 & 21,6 & 29,6 & 16,4 & 11,2 \\
\hline \multirow{2}{*}{$\begin{array}{l}\text { 26. I can benefit from the } \\
\text { garden of the dormitory } \\
\text { building adequately. }\end{array}$} & $\bar{f}$ & 58 & 44 & 72 & 44 & 32 \\
\hline & $\%$ & 23,2 & 17,6 & 28,8 & 17,6 & 12,8 \\
\hline \multirow{2}{*}{$\begin{array}{l}\text { 27. The dormitory building } \\
\text { generally meets the } \\
\text { expectations of a university } \\
\text { student. }\end{array}$} & $\mathbf{f}$ & 116 & 50 & 38 & 28 & 18 \\
\hline & $\%$ & 46,4 & 20 & 15,2 & 11,2 & 7,2 \\
\hline \multirow{2}{*}{$\begin{array}{l}\text { 28. The façade features of the } \\
\text { building (color, material, } \\
\text { shape, etc.) are effective in } \\
\text { choosing this dormitory. }\end{array}$} & f & 33 & 66 & 87 & 45 & 19 \\
\hline & $\%$ & 13,2 & 26,4 & 34,8 & 18 & 7,6 \\
\hline
\end{tabular}

- For the statement "I think that the area of study is enough", $28,8 \%$ of students responded as "I disagree" and $28,4 \%$ of that stated as "I agree little". It is known that there is a study 
area in rooms in all the dormitories which were examined before. In this case, the obtained results are thought to be related to the positions of these areas and the insufficiency of their functional area in the rooms. Accordingly, these results support the criteria proposed in $\mathrm{C}_{3}$.

- While for the statement "I'm pleased with the location of the study area in the room" $28,4 \%$ of the students answered as "I didn't agree"; for the same statement, $37,2 \%$ of them said that they agree partially. As stated before, these results are concerned with the criteria in $\mathrm{C}_{3}$.

- In terms of the adequacy of the service areas in the dormitory buildings, students answered at the rate of $21 \%$ for the statement of "Not enough at all" and at the rate of 21.6 for the statement "Less than enough". These results support the criteria proposed in $\mathrm{C}_{4}$.

- It is considered that the dormitory building should not only have a sleeping area but also the areas where students can perform their social and cultural activities. So, in the survey, one of the statements was related to the sufficiency of social areas for spending the students' free time. About the statement, $37,2 \%$ of the participants had a negative opinion. These results support the criteria in $\mathrm{C}_{5}$.

- The statement "The façade features of the building (color, material, shape, etc.) are effective in choosing this dormitory" was asked by expectations that façade features are effective on the preference of dormitory buildings. $34.8 \%$ of the students at intermediate level and $26.4 \%$ of them at less level concurred with this opinion. These results don't support the criteria proposed in $\mathrm{C}_{6}$.

- Finally, the responses are interesting for the statement "The dormitory building generally meets the expectations of a university student" because $46 \%$ of students said that they disagree.

\section{RESULTS AND SUGGESTIONS}

Dormitory buildings are the type of building where the other different needs of the student who are away from their family are met in addition to that of accommodation. In this context, the design solutions of a dormitory with good planning are important for providing the support, which a student needs in the phase that they start to acquire new experiences by themselves.

In this study, students' expectations from a dormitory building and their satisfaction with the dormitory where they reside were investigated. In the previous researches, it was pointed out that the physical properties of a dormitory building affected students' physical and psychological requirements. In the consideration of 
that meeting these requirements is directly effective on the satisfaction, it was also important to analyze the criteria which affected them. By using the obtained results from the survey for analyses of them the attention was drawn to develop the qualifications of existing spatial elements in the dormitory buildings. Accordingly, from the results of survey and literature studies the evaluations can be explained as follow:

In most of the case studies presented in this paper, it seems that there is a general tendency on suite-style dormitories. In Karabük, this tendency is also supported by the preferences of $45 \%$ group on student home and the answers to questions concerned with using specialized and common spaces for students' basic needs.

Taking care of the answer to the question of "Crowd" sense and the case of that public dormitories were the last choice in the survey, as stated before, it is considered that sense of belonging is weak in these dormitories due to their high capacities and their locations away from the city center despite the positive architectural planning in their rooms. Besides, it is known that the increase in numbers of people may cause to existence of an environment where students do not like to live. Therefore, a more formal environment is another important obstacle to the acquisition of a sense of belonging (Adler, 1999).

In the recent regulations, students are permitted to stay in the rooms, the capacities of which consist of one, three, four, five and six people. However, it is interesting that students usually preferred the room with two people in the survey. This case may be concerned with the existence of social relationships in Turkish society, unlike Western societies (Kaya \& Weber, 2003). It is considered that students' desire to have at least one other person in the room may be related to fear of loneliness and to a certain level of socialization.

While architectural plans of dormitories are examined, it is seen that studying areas for students are defined (Öztürk, 2017) However, about $57 \%$ of participants $(28,8 \%$ of participants disagreed and $28.4 \%$ of them agreed partially) said that studying areas are insufficient in the survey. Additionally, almost half of the participants stated their displeasures about the placements/positions of their studying areas $(28,4 \%$ of participants disagreed and $21.6 \%$ of them agreed partially). Here the significant part of the participants in the survey was comprised of the students who were educated in the departments of painting and architecture and architectural restorations. For these students, when the content of the curriculums of the departments is examined in detail, the need for special study areas emerges. This situation is effective in the results. So, in the designs of these buildings, as in the study of 
Filiz and Çemrek (2007), it should be considered that different spatial requirements can be needed for the students educated in different fields.

As another result, while the answers to the compatibility between numbers of furniture and numbers of people in a dorm room are positive (31,2\% of participants agreed completely and $16.4 \%$ of them mostly agreed), the rate of satisfaction in settlement organization of furniture is lower $(9,2 \%$ of participants agreed completely and $18 \%$ of them mostly agreed). Accordingly, in the scale of Karabük, it is possible to conclude that both quantitative and qualitative values should be considered. In this way, as Yildirim and Uzun (2010) pointed out before, it is necessary to pay attention to defined personal using areas and physiological processes.

In the dormitory buildings, it is important to support students in terms of their socialization needs as well as meeting the personal basic requirements. Besides, most of the students stated that there should be resting areas as common spaces in the dormitories. However, they pointed out the insufficiency of the social activity areas that are designed for leisure times. In the dormitories in Karabük and their design briefs, the spaces like rest-TV room, multi-purpose hall, indoor and outdoor areas for sports activities are generally taken place (Öztürk, 2017). Nevertheless, it is considered that this contradiction exists due to users' different demands, lack of diversity in this aspect and insufficiencies of size and physical conditions of the spaces for this aim.

Besides the design problems of the dormitories, it should be remembered that some dissatisfactions are originated from the emergence of some administrative mistakes like the increase in the numbers of the users and positioning the spaces in the places in the building out of initial planning. Regarding the issue, it is known that physical opportunities at first and administrative satisfactions later are preferential in student' service purchasing decisions (Ayaz \& Başdağ, 2016).

In spatial analyses of dormitory buildings, the focus is generally on the sleeping areas. Naturally, in the ranking of design criteria, the arrangements of the social areas remain in the background. Therefore, in the design of social areas, by taking care of that these areas are changeable according to the conditions, their solutions should be more qualified, flexible, sustainable, and suitable for their functions. Additionally, the control of the spatial qualities in these areas should be supported by rules of the regulations. 


\section{REFERENCE}

Adler, D. D. (1999). Pride, L. Student Housing and Housing for Young People. In Metric Handbook Planning and Design Data.

Ayaz, N., \& Başdağ, S. (2016). Üniversite Öğrencilerinin Özel Yurt Satın Alma Davranışı: Karabük İli Örneği. Karabük Üniversitesi Sosyal Bilimler Enstitüsü Dergisi, 2, 79-98.

Çağatay, K., Yalçın, M., \& Yıldırım, K. (2014). Öğrenci Yurdu Odalarının Mekân Kalitesinin Kullanıcıların Fonksiyonel ve Algısal Performansı Üzerine Etkisi; Tahsin Banguoğlu Örneği. Tasarım + Kuram, 10(18), 53-53.

Demirbilek, M. (2012). Yurtlarda kalan öğrencilerin arkadaşlık ilişkileri, arkadaşlık ilişkileriyle bağlantılı sorunları ve çözümüne yönelik bir model denemesi. Ankara Sağllk Bilimleri Dergisi, 1(3), 1-24.

Devlin, A. S., Donovan, S., Nicolov, A., Nold, O., \& Zandan, G. (2008). Residence hall architecture and sense of community: Everything old is new again. Environment and Behavior, 40(4), 487-521.

Filiz, Z., \& Çemrek, F. (2007). Üniversite Öğrencilerinin Barınma Sorunlarının Uygunluk Analizi İle İncelenmesi. Eskişehir Osmangazi Üniversitesi Sosyal Bilimler Dergisi, 8(2), 207224.

İnceoğlu, N. (1995). Bir Araştırmanın Düşündürdükleri Öğrenci Yurtlarında Planlama Sorunları. Mimarlık Dergisi, 265(5), 14-16.

Kaya, N., \& Erkip, F. (2001). Satisfaction in a dormitory building. The effects of floor height on the perception of room size and crowding. Environment and Behavior, 33(1), 35-53.

Kaya, N., \& Weber, M. J. (2003). Cross-cultural differences in the perception of crowding and privacy regulation: American and Turkish students. Journal of Environmental Psychology, 23(3), 301-309.

Khajehzadeh, I., \& Vale, B. (2014). Shared Spaces in a Student Dorm: A Post Occupancy Evaluation. Across Architectural Research through to Practice: 48th Interna- Tional Conference of the Architectural Science Association, Italy 163-174.

Khozaei, F., Hassan, A. S., Al Kodmany, K., \& Arab, Y. (2014). Examination of student housing preferences, their similarities and differences. Facilities, 32(11/12), 709-722.

Öztürk, M. (2017). Karabük'te Bulunan Yükseköğrenim Öğrenci Yurtlarının Yurt Binası Planlama İlkeleri Bağlamında Değerlendirilmesi. Karabük Üniversitesi.

Rodger, S. C., \& Johnson, A. M. (2005). The impact of residence design on freshman outcomes: Dormitories versus suitestyle residences. The Canadian Journal of Higher Education, XXXV(3), 83-89.

Yildirim, K., \& Uzun, O. (2010). The effects of space quality of dormitory rooms on functional and perceptual performance of Users: Zübeyde hanim sorority. Gazi University Journal of Science, 23(4), 519-530. 


\section{Resume}

S. Merve Öztürk received her Bachelor Degree from Balıkesir University, Department of Architecture in 2013. She is a Research Assistant in the Faculty of Architecture at Karabük University. She is currently continuing her PhD study at Eskișehir Technical University.

Ahmet Emre DiNÇER was graduated from ITU, Department of Architecture in 2005. He received Master and PhD degrees from ITU Graduate School of Science Engineering and Technology in 2008 and 2014. He has been working as an assistant professor at Karabük University since 2014. His main research area is Architectural Design Computing. 